\section{Colonial Products Research Council}

THE Colonial Office has appointed a Colonial Products Research Council, under the chairmanship of Lord Hankey. Unlike the Colonial Research Committee under Lord Hailey, the Council will be an executive body. It will consider what Colonial raw materials may be made of value for the manufacture of intermediate and other products required by industry, and it will initiate and supervise researches, both pure and applied, on such products, and generally consider how by the application of research greater use can be made of them. In framing its programme the Council will have as its principal objective the promotion of the welfare and prosperity of Colonial peoples, and will endeavour also to increase the Colonial contribution to the welfare and prosperity of the British Empire and of the world as a whole. In carrying out its programme, the Council will co-operate with existing institutes, such as the Department of Scientific and Industrial Research, the Medical Research Council, and the Agricultural Research Council, to the greatest possible extent, and will 'farm out' work to these and other bodies by arrangement; it will set up facilities of its own only for work which cannot be done by other means. So long as the war continues, the investigations which the Council will be able to undertake will necessarily be limited.

The Council is composed as follows: Mr. Eric Barnard, director of food investigation, Department of Scientific and Industrial Research ; Capt. G. L. M. Clauson, assistant Under-Secretary of State, Colonial Office ; Mr. Aneurin Davies; Dr. J. J. Fox, Government chemist; Prof. W. N. Haworth, professor of chemistry, University of Birmingham; Sir Harry Lindsay, director of the Imperial Institute; Sir Edward Mellanby, secretary, Medical Research Council ; Sir Robert Robinson, Waynflete professor of chemistry, University of Oxford; Mr. G. W. Thomson, president, National Federation of Professional Workers; and Dr. W. W. C. Topley, secretary, Agricultural Research Council. Prof. J. L. Simonsen, lately of the University College of North Wales, has been appointed director of research. Certain members of the Council are also members of the Colonial Research Committee, and the Council will work in close touch with that body. It will be financed out of the provision for research in the Colonial Development and Welfare Act.

\section{A Photographic Record of the Linnean Collections}

Tre value of the Linnean collections of animals and plants and of the associated books and manuscripts needs no emphasis. They must always remain of supreme importance to systematists, and the Linnean Society of London has very rightly regarded them as its own special charge. In April 1939 the collections were moved for safety to Woburn Abbey in Bedfordshire, and with the advent of bombing raids in 1940 the Linnean Society, through its Council, took steps for preserving a photographic record of the collections. A generous grant of about $£ 2,000$ was made to the Society by the Carnegie Corporation of America for this purpose and the work took active shape in the latter half of 1941. In order to facilitate the work the collections were removed in July of that year to the Zoological Museum at Tring, formerly the property of Lord Rothschild and now a department of the British Museum (Natural History). It was decided to adopt photographs on $35-\mathrm{mm}$. microfilm and, by this means, it was estimated that it would be possible to make a complete reaord of all the specimens, books and manuscripts in the course of about nine months. In addition, this would allow of a copy of the finished film being sent to the United States and possibly others elsewhere. As an indication of the extent of the task it may be pointed out that the estimated number of exposures in the case of the plants was 14,000, for the insects 5,000, for the shells 2,000 , for the fishes 158 , and for the books and manuscripts 30,000-making altogether more than 60,000 exposures. Good progress has been made, and it is probable that the whole of the work will be completed well within the estimated period. The details of the steps taken and how the various difficulties were encountered, together with the services rendered by various specialists, are recounted in an article on the subject by J. R. Norman in the Proceedings of the Linnean Society for 1941-42 (Part 1, pp. $49-57$ ).

\section{Investigations in Afghanistan}

Mr. K. DE B. CoDRINGTON has recently returned from Afghanistan. He joined Josef Hackin, director of the French Archæological Mission, in the spring of 1940 and was present during his last season's work at Begram, the site north of Kabul which has produced such remarkable finds. M. Hackin left Kabul in the autumn of 1940 to join General de Gaulle's staff in London, and later lost his life at sea. Mr. Codrington interested himself in the Afghan Government's recent adoption of Pushto as the national language, and wrote an introductory grammar of Kandahari Pushto in collaboration with Colonel Muhammad Yaqub Khan. He speaks warmly of the Afghan Government's interest in archæology and history, and of the work of the staff of the Kabul Museum and the Kabul Literary Society, who are engaged upon a national history. Through the kindness of H.R.H. Sardar Naim Khan, the Minister of Education, and of H.R.H. Shah Mahmud, the Minister of National Defence, Mr. Codrington was able to make collections of flowering plants and varieties of wheat. He also contributed specimens of fishes to the Zoological Survey of India. Certain specimens of Afghan wheat are already being grown at Cambridge, and it is hoped to carry this work further, with the assistance of the Afghan authorities.

\section{Vitamin Production in the U.S.S.R.}

At a Conference of Biochemists held in Moscow last November, attention was directed to the possibilities of utilizing the extensive walnut forests of Kazakhstan as an almost inexhaustible source of vitamin C. The unripe walnut contains an unusual quantity of ascorbic acid, and vitamin $\mathrm{C}$ is already being manufactured from it on a commercial scale. It is hoped that the systematic exploitation of the walnut forests for vitamin $\mathrm{C}$ production will be fully organized this year. Many hospitals in northern districts successfully use an infusion of pine needles as a means of supplying vitamin C. Other measures adopted since the War for increasing supplies of vitamins include the production of yeast (as well as protein) from food waste, the manufacture of vitamin $B_{6}$ from tobaceo waste, and the utilization of certain freshwater fish as sources of vitamin $\mathbf{D}$. 